N. YE. NAUMENKO, M. B. SOBOLEVSKAYA, D. V. GOROBETS, YE. G. BOGOMAZ

\title{
DEVELOPMENT OF ELEMENTS OF PASSIVE SAFETY FOR NEW- GENERATION HIGH-SPEED PASSENGER LOCOMOTIVES AT EMERGENCY COLLISIONS ON RAILWAYS WITH 1520 MM GAUGE
}

Institute of Technical Mechanics of the National Academy of Sciences of Ukraine and the State Space Agency of Ukraine, 15, Leshko-Popel Str., Dnepr, Ukraine, 49005, e-mail: dep7@ukr.net

In the design of a new-generation locomotive, an integrated passive safety system (PSS) must be considered to protect passengers and a train staff at probable emergency collisions. The paper discusses a scenario of a collision between the reference train and 80 -ton freight car at $36 \mathrm{~km}$ an hour. The reference train includes the locomotive equipped by SSP with energy absorption devices (EAD), and the 80-ton freight car. This scenario is provided by the European standard EN 15227. The research purpose is to develop the EAD for new-generation passenger 90-123-ton locomotives. To determine the EAD integral parameters, namely the power intensity, a dynamic load of the locomotive is studied using a mathematical discrete-mass model. The novelty of this model is to improve the power characteristic of interactions between vehicles taking into accounts the operation of the absorbing devices of shifted automatic couplers and EAD, as well as the possibility of plastic deformation occurring in the EAD design and vehicles. The paper also presents a new finite element model of the EAD plastic deformation at impact. This model has been used to develop the EAD with the power intensity of $0.95 \mathrm{MJ}$ and to select the EAD parameters. It is shown that the two energy-absorbing device installed at ends of the locomotive can provide the collision scenario in accordance with the requirements of European standard EN 15227 and the developed concept of the passive safety for passenger rolling stock operating on railways with $1520 \mathrm{~mm}$ gauge.

Keywords high-speed passenger locomotive, collision, passive safety system, energy-absorbing device.

1. EN 15227. Railway Applications - Crashworthiness Requirements for Railway Vehicle Bodies. Brussels, 2008. $37 \mathrm{p}$.

2. GOST 32410-2013 (EN 15227: 2008+A1: 2010, NEQ). Interstate Standard. Crash-Systems of Railway Rolling Stock for Passenger Transportation. Technical Requirements and Control Methods. M., 2014. 11 p.

3. Carl F.B., Schneider S., Wolter W. Development of the crashworthy locomotive platform TRAXX: Operational needs, technical concept and validation procedure. Passive Safety of Rail Vehicles and Safe Interiors. Proceedings of the $5^{\text {th }}$ International Symposium (March 17-18, 2005, Berlin). Berlin, 2005. P. $42-62$.

4. Foedtke J., Schneider S., Pfrommer R., Zurheide H. Entwicklung der Kastenstruktur für die Lokomotive Voith Maxima 40CC. Design of the carbody structure for the Voith Maxima 40CC locomotive. ZEVrail Glasers Annalen. 2008. № 132. . $292-303$.

5. Prima II: New-Generation Locomotives. Zheleznye Dorogi Mira. 2010. No 12. P. 17 - 25.

6. The EST crash buffer. URL: http://www.crashbuffer.com/index.htm (Last accessed: 17.02.2017).

7. Wasilewski L. Evolution of crash absorbing systems according to EN 15227 and according to real operation conditions. Passive Safety 2013 - Passive Safety of Rail Vehicles and Safe Interiors. Proceedings of the $9^{\text {th }}$ International Symposium (February 21-23, 2013, Berlin). Berlin, 2013. P. $211-218$.

8. Llana P., Stringfellow R. Preliminary development of locomotive crashworthy components. Proceedings of the ASME/ASCE/IEEE 2011 Joint Rail Conference JRC2011, Pueblo, Colorado, USA. 2011. P. 11 - 20.

9. Llana P., Stringfellow R., Mayville R. Finite Element Analysis and Full-Scale Testing of Locomotive Crashworthy Components. Volpe National Transportation Systems Center. 2013. $11 \mathrm{p}$. URL: http://ntl.bts.gov/lib/47000/47400/47410/JRC2013-2546_Loco_CW_Comp_Tests_FINAL.pdf (Last accessed: 17.02.2017).

10. Carolan M., Perlman B., Tyrell D. Alternative Occupied Volume Integrity (OVI) Tests and Analyses. Volpe National Transportation Systems Center. 2013. 134 p. URL: http://ntl.bts.gov/lib/48000/48300/ 48366/TR_Alternative_OVI_Testing_Report_edited_20131024_FINAL_1_.pdf (Last accessed: 17.02.2017).

11. Tyrell D., Llana P. Locomotive crashworthiness research // Volpe National Transportation Systems Center. 2015. - 14 p. URL: http://ntl.bts.gov/lib/60000/60000/60019/IMECHE_Conf_Locomotive_crashworthiness _research.pdf (Last accessed: 17.02.2017).

12. Llana P., Tyrell D., Rakoczy P. Conventional Locomotive Coupling Tests: Test Requirements and Pre-Test Analysis. Volpe National Transportation Systems Center. - 2016. - 7 p. URL: http://ntl.bts.gov/lib/59000/59400/ 59405/JRC2016-5817_Locomotive_Coupling_Tests.pdf (Last accessed: 17.02.2017).

13. Sobolevskaya M. B., Sirota S. A. Basic concepts of passive protection of high-speed passenger train at emergency collision. Tekhnicheskaya Mekhanika. 2015. No 1. P. 84 - 96.

14. Naumenko N. Ye., Khizha I. Yu. Assessment of operational effects of devices for passive safety of passenger locomotive on its dynamic loading at emergency collision with obstacle on railway. Nauka ta Progres Transportu. Visnyk Dnipropetrovskogo Universitetu Zaliznychnogo Transportu im. Akad. V. Lazaryana. 2013. No 1(43). P. 154 - 160. 
15. Sobolevskaya M. B., Sirota S. A., Gorobets D. V., Telichko I. B. Development of energy-absorbing devices for passive safety of railway rolling stock(numerical simulation and crash-test). Abstracts for $75^{\text {th }}$ International Conference on Problems and Prospects of Railway Transport. (May 14 - 15, 2015, Dniepropetrovsk). Dniepropetrovsk, 2015. P. 103 - 104.

16. Sobolevska M., Telychko I. Passive safety system of an electric locomotive for high-speed operation on the railways with $1520 \mathrm{~mm}$ gauge. Passive Safety 2013 - Passive Safety of Rail Vehicles and Safe Interiors. Proceedings of the $9^{\text {th }}$ International Symposium (February 21- 22, 2013, Berlin). Berlin, 2013. P. $63-80$.

17. Gonorovsky I. S. Radio Engineering Circuits and Signals: Textbook. M.: 1986. 512 p. 